\title{
Surfactant Modulates Intracellular Signaling of the Adhesion Receptor L-Selectin
}

\author{
BIRGIT BRENNER, SONJA JUNGE, ALEXANDRA BIRLE, STEPHANIE KADEL, AND \\ OTWIN LINDERKAMP \\ Department of Pediatrics, Division of Neonatology, Im Neuenheimer Feld 150, 69120 Heidelberg, \\ Germany
}

\section{ABSTRACT}

\begin{abstract}
Intraalveolar leukocyte accumulation is one of the hallmarks during respiratory distress. In the intraalveolar space, leukocyte activation is mediated by pathogens, cytokines, and different ligands binding to adhesion molecules. Leukocyte stimulation via the adhesion molecule L-selectin is specifically induced by ligands expressed on leukocytes, platelets, endothelial cells, or lipopolysaccharide. Recently, we have demonstrated that leukocyte activation by L-selectin transmits several intracellular signaling cascades resulting in capping and cytoskeletal changes, the activation of kinases and neutral sphingomyelinase, the recruitment of adaptor proteins to the cell membrane, the activation of the small G-proteins Ras and Rac, and the release of oxygen. In the present study, we examined the effects of surfactant on L-selectin-induced signal transduction in leukocytes. Using fluorescence microscopy, we provide evidence that preincubation of leukocytes with surfactant significantly inhibits receptor capping; $28 \pm 7 \%$ of cells show capping after L-selectin stimulation versus
\end{abstract}

$8 \pm 5 \%$ and $3 \pm 1 \%$ of cells after preincubation with Exosurf and Curosurf, respectively $(p<0.05)$. The activity of the neutral sphingomyelinase in cell lysates is also modulated by surfactant. In addition, we show that the activation of the tyrosine kinase p56lck is diminished by approximately 50\% after surfactant treatment. This results in inhibition in tyrosine phosphorylation of certain intracellular proteins. The interaction of the L-selectin molecule with its antibody was not influenced by surfactant as shown by flow cytometry. Surfactant inhibits intracellular signaling events of the L-selectin receptor in leukocytes and might therefore contribute to the modulatory effects of surfactant on immune function. (Pediatr Res 48: 283-288, 2000)

CLD, chronic lung disease

LPS, lipopolysaccharide

RDS, neonatal respiratory distress syndrome
Leukocyte trafficking and extravasation of leukocytes into the intraalveolar space is a common feature in pneumonia, pulmonary failure, and RDS of the premature infant $(1,2)$. This key event in the immune response to pathogens or inflammatory stimuli is mediated mainly by chemokines and adhesion molecules (3). Initially, leukocytes roll on endothelial cells before they firmly adhere and finally extravasate in the surrounding tissue. Rolling and tethering of leukocytes on endothelial cells are transient interactions mediated by selectin molecules, and sticking and transmigration depends on integrins and Ig-like receptors.

In the course of respiratory distress syndrome, activated intraalveolar leukocytes secrete chemokines, enzymes like elastase, and oxygen radicals in response to inflammatory stimuli $(4,5)$. Excessive leukocyte accumulation and activation results in tissue destruction and exacerbation of the inflammatory cascade (6). The development of CLD in preterm infants

Received June 30, 1999; accepted March 31, 2000.

Correspondence: Birgit Brenner, MD, Department of Pediatrics, Division of Neonatology, Im Neuenheimer Feld 150, 69120 Heidelberg, Germany.

Supported by a grant from the German Research Foundation to B.B. (Br 1619/5-1). seems to be partly caused by neutrophil and lymphocyte activation $(7,8)$.

Recently, we and others have demonstrated that leukocytes get activated via the adhesion molecule L-selectin by the induction of intracellular signaling events $(9-11)$. L-selectin is constitutively expressed on all leukocytes with a calciumdependent lectin domain for ligand recognition and a short intracellular tail. Carbohydrate ligands on leukocytes, platelets, and endothelial cells and LPS interact specifically with the L-selectin receptor, thereby inducing intracellular signaling cascades. Stimulation of the L-selectin molecule activates the tyrosine kinase p561ck and the Ras signaling pathway (11). L-selectin triggering results in a release of oxygen radicals, cytoskeletal changes, and activation of stress-activated protein kinases $(12,13)$ (Fig. 1). In addition, there is an increase in synthesis of mRNA for tumor necrosis factor- $\alpha$ and IL-8 (11), important chemokines in the pathogenesis of respiratory distress syndrome causing tissue destruction, and thereby promoting the development of CLD $(4,14)$.

L-selectin triggering goes along with shedding of this receptor, i.e. proteolytic cleavage of the extracellular part (15). 


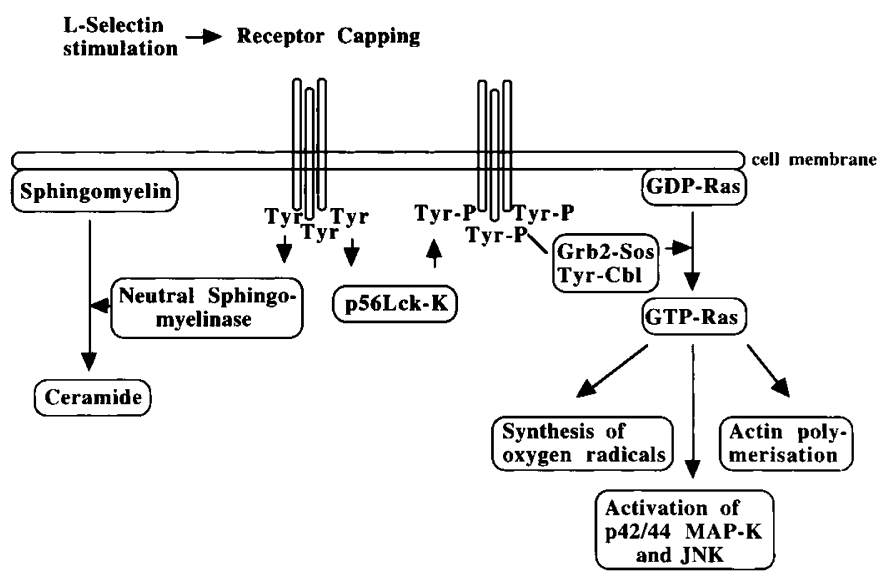

Figure 1. Summary of intracellular signaling cascades in lymphocytes on L-selectin triggering $((9-13,24,25)$. L-selectin triggering results in receptor capping and the activation of two independent signaling cascades: L-selectin stimulation leads to a p56lck-tyrosine kinase-dependent activation of the small $\mathrm{G}$ proteins Ras and Rac, followed by activation of MAP-kinase and stressactivated protein kinases (SAPK $=\mathrm{JNK})$, actin polymerization, and synthesis of oxygen radicals. In addition, L-selectin cross-linking activates the neutral sphingomyelinase independent of p56lck, resulting in consumption of cellular sphingomyelin and an increase in ceramide.

Increased level of soluble L-selectin in the intraalveolar space of preterm infants suffering from acute respiratory distress syndrome therefore reflects an L-selectin-mediated activation of leukocytes (16).

Pulmonary surfactant lowers the surface tension in alveoli, and the replacement in RDS means a causative therapy. However, there is growing evidence that surfactant suppresses immune functions induced during lung injury (17). The potential effects of surfactant on intracellular signal transduction events of adhesion molecules in leukocytes have not been studied until now. Here we provide experimental evidence for an immunomodulatory role of surfactant in L-selectin-induced signaling.

\section{METHODS}

Cell culture and stimulation. All reagents were purchased from Sigma Chemical Company (Deisenhofen, Germany), if not otherwise cited. The human leukemic $\mathrm{T}$ cell line Jurkat (American Type Culture Collection, Rockville, MD, U.S.A.) was grown in RPMI 1640 medium supplemented with $10 \%$ FCS, $10 \mathrm{mM}$ HEPES (pH 7.4), $2 \mathrm{mM}$ L-glutamine, $1 \mathrm{mM}$ sodium pyruvate, $100 \mathrm{mM}$ nonessential amino acids, 100 $\mathrm{U} / \mathrm{mL}$ penicillin, $100 \mathrm{mg} / \mathrm{mL}$ streptomycin (all purchased from GIBCO BRL, Karlsruhe, Germany), and $50 \mathrm{mM} \beta$-mercaptoethanol. We used Jurkat cells in all experiments because we have shown previously that L-selectin triggering induces the same signaling events in this cell line as in peripheral blood lymphocytes or neutrophils, pointing to the biologic significance of signaling events in Jurkat cells (11).

For activation, cells $\left(2 \times 10^{6}\right.$ or $20 \times 10^{6}$ per sample for total cell lysates or immunoprecipitations, respectively) were washed twice in sterile HEPES/saline (H/S: $132 \mathrm{mM} \mathrm{NaCl}, 20$ mM HEPES, $5 \mathrm{mM} \mathrm{KCl}, 1 \mathrm{mM} \mathrm{CaCl} 2,0.7 \mathrm{mM} \mathrm{MgCl}_{2}, 0.8$

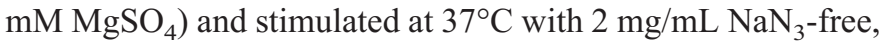

low endotoxin, monoclonal anti-human L-selectin antibody (Dreg56, Pharmingen, CA, U.S.A.) for the indicated times. The Dreg56 antibody has been previously shown to recognize the lectin domain of $\mathrm{L}$-selectin and to stimulate leukocytes $(9-11$, $18,19)$.

Surfactant. For studying the influence of surfactant on L-selectin-induced signaling events, Curosurf $(500 \mu \mathrm{g} / \mathrm{mL})$ or Exosurf $(1 \mu \mathrm{g} / \mathrm{mL})$, reflecting the amount of dipalmitoyl phosphatidylcholine in the preparation, were added in all experiments to the cells $30 \mathrm{~min}$ before cell stimulation. These concentrations were in the same range of the concentration of synthetic surfactant $(20,21)$ or natural porcine surfactant $(22$, $23)$, respectively, used previously in experiments studying the modulating effects of surfactant on immune function, e.g. cytokine synthesis, synthesis of superoxide anions, and activation of transcription factors. Cell viability of untreated and treated with surfactant-incubated lymphocytes at the end of the experiment was tested by trypan blue staining.

Immunoprecipitation and immunoblotting. Cell stimulation was terminated by lysis in $25 \mathrm{mM}$ HEPES (pH 7.4), $0.1 \%$ SDS, $0.5 \%$ sodium deoxycholate, $1 \%$ Triton X-100, $125 \mathrm{mM}$ $\mathrm{NaCl}, 10 \mathrm{mM}$ each of $\mathrm{NaF}, \mathrm{Na}_{3} \mathrm{VO}_{4}$, and sodium pyrophosphate, and $10 \mu \mathrm{g} / \mathrm{mL}$ each of aprotinin and leupeptin (RIPAbuffer) for total cell lysates and for immunoprecipitation of the L-selectin molecule. Cells were lysed in 3\% NP-40, $25 \mathrm{mM}$ HEPES (pH 7.4), $100 \mathrm{mM} \mathrm{NaCl}, 10 \mathrm{mM}$ each of $\mathrm{Na}_{3} \mathrm{VO}_{4}$, $\mathrm{NaF}$, EDTA, and sodium pyrophosphate, and aprotinin plus leupeptin (10 $\mu \mathrm{g} / \mathrm{mL}$ each; TN3 buffer) to determine src-kinase activity. Anti-lck, monoclonal anti-phosphotyrosine 4G10, and anti-Cbl antibodies were purchased from Upstate Biotechnology, Inc. (UBI, Lake Placid, NY, U.S.A.).

After lysis, DNA and cell debris were pelleted by centrifugation at 20,000 $\times g$ for $15 \mathrm{~min}$, and samples were immunoprecipitated for $4 \mathrm{~h}$ at $4{ }^{\circ} \mathrm{C}$ using $3 \mu \mathrm{g}$ of each antibody. After addition of protein A/G Plus agarose (Santa Cruz, Heidelberg, Germany), incubation was continued for at least $60 \mathrm{~min}$. Immunocomplexes were washed six times in lysis buffer and applied to kinase assays or resuspended in SDS sample buffer (60 mM Tris, pH 6.8, 2.3\% SDS, $10 \%$ glycerol, $5 \% \beta$-mercaptoethanol). Separation of proteins was performed by SDS/ PAGE, followed by an electrophoretic transfer to PVDF membranes (BioRad, Munich, Germany). Blots were incubated overnight at $4{ }^{\circ} \mathrm{C}$ with the appropriate antibody (each diluted to $0.5 \mathrm{mg} / \mathrm{mL}$ in Tris-buffered saline, supplemented with $0.1 \%$ Tween 20). Immunoblots were developed by incubation with horseradish peroxidase-conjugated protein G (BioRad, Munich, Germany) and use of a chemoluminescence kit (Amersham, Braunschweig, Germany).

Src-kinase assays. The src-kinase $\mathrm{p} 56^{\mathrm{lck}}$ was immunoprecipitated using an agarose-coupled anti-p56 $6^{\mathrm{lck}}$-antibody (UBI). Immunoprecipitates were incubated for $4 \mathrm{~h}$ at $4^{\circ} \mathrm{C}$ as described above, washed four times in lysis buffer (TN3) and twice in kinase buffer ( $25 \mathrm{mM}$ HEPES, pH 7.0, $150 \mathrm{mM} \mathrm{NaCl}, 10 \mathrm{mM}$ $\mathrm{MnCl}_{2}, 1 \mathrm{mM} \mathrm{Na} \mathrm{VO}_{4}, 5 \mathrm{mM}$ DTT, and $0.5 \%$ NP-40). The reaction was initiated by addition of $10 \mu \mathrm{Ci}\left[{ }^{32} \mathrm{P}\right] \gamma \mathrm{ATP}(3000$ $\mathrm{Ci} / \mathrm{mmol}$, NEN Du Pont, Bad Homburg, Germany), ATP (10 $\mu \mathrm{M})$, and, as substrate, enolase (200 $\mu \mathrm{g} / \mathrm{mL}$; Sigma) in kinase buffer to the resuspended samples. Samples were incubated at 
$30^{\circ} \mathrm{C}$ for $20 \mathrm{~min}$, the reaction was stopped with $8 \mu \mathrm{L}$ of reducing $5 \times$ SDS sample buffer, and SDS/PAGE was performed followed by autoradiography. An aliquot of the immunoprecipitates was separated on SDS/PAGE and blotted with an anti-lck antibody to check for equal amounts of protein in each lane.

Activity of neutral sphingomyelinase. For determination of neutral sphingomyelinase activity, cells $\left(10 \times 10^{6}\right)$ were stimulated with $2 \mu \mathrm{g} / \mathrm{mL}$ monoclonal anti-human-L-selectin antibody, lysed in a buffer consisting of $20 \mathrm{mM}$ HEPES ( $\mathrm{pH}$ 7.4), $5 \mathrm{mM}$ DTT, $2 \mathrm{mM}$ EDTA, $10 \mathrm{mM} \mathrm{MgCl} 2,0.1 \mathrm{mM} \mathrm{Na}_{3} \mathrm{VO}_{4}$, $10 \mathrm{mM} \beta$-glycerophosphate, $7.5 \mathrm{mM}$ ATP, $10 \mathrm{mM}$ leupeptin, and $0.2 \%$ Triton $X-100$. Samples were immediately sonicated three times for $10 \mathrm{~s}$, and insoluble cell debris was pelleted by 5 min centrifugation at $600 \times g$. The substrate $\left[{ }^{14} \mathrm{C}\right]$ sphingomyelin $(0.5 \mathrm{mCi} / \mathrm{sample}, 54.5 \mathrm{mCi} / \mathrm{mmol}$; NEN DuPont $)$ was added, samples were incubated for $90 \mathrm{~min}$ at $37^{\circ} \mathrm{C}$ and extracted with chloroform-methanol $(2: 1)$ and $\mathrm{H}_{2} \mathrm{O}$, the upper phase was collected, and radioactivity reflecting the degradation of $\left[{ }^{14} \mathrm{C}\right]$ sphingomyelin was determined by liquid scintillation counting.

Flow cytometry. To analyze antibody-receptor interaction in the presence and absence of two different surfactant preparations, Jurkat cells were stained with an FITC-labeled L-selectin antibody (Dianova-Immunotech, Hamburg, Germany). Cells were washed twice again, and typically $10^{4}$ cells were analyzed for binding of FITC-anti-L-selectin antibodies by flow cytometry using a FACScan (Becton-Dickinson, Heidelberg, Germany).

Fluorescent staining and microscopy. Cells $\left(1 \times 10^{6}\right.$ per sample) were washed and stimulated with the Dreg56 antibody as described above. Cell stimulation was terminated by washing the samples twice in ice-cold staining buffer $(\mathrm{H} / \mathrm{S}, 2 \% \mathrm{FCS}$, $\left.0.2 \% \mathrm{NaN}_{3}\right)$, stained at $4^{\circ} \mathrm{C}$ with FITC-anti-L-selectin (10 $\mu \mathrm{g} / \mathrm{mL}$ ) for $30 \mathrm{~min}$. Stained and washed cells were fixed in $4 \%$ paraformaldehyde and analyzed by fluorescence microscopy as described previously by Junge et al. (24). In each experiment, 50-100 cells were analyzed and scored for capping. Capping cells showed one or several intense fluorescence spots on the cell surface, whereas in noncapping cells, fluorescence was distributed evenly throughout the membrane. Scoring was confirmed by two observers independently.

Statistical analyses. Results of each experimental group are calculated as mean $\pm \mathrm{SD}$ of the mean. To test for statistical significance of the differences between the experimental groups, the Student's $t$ test or the Mann-Whitney $U$ test was used when appropriate. A $p$ value of $<0.05$ was considered statistically significant. Experiments were repeated at least three times if nothing other is stated.

\section{RESULTS}

Surfactant (Curosurf and Exosurf) does not influence ligand recognition of the L-selectin molecule. Jurkat $\mathrm{T}$ lymphocytes were stained for the L-selectin molecule using the Dreg56 L-selectin antibody and an FITC-labeled secondary antibody. Jurkat cells stained positively for L-selectin as determined by flow cytometry (Fig. 2). Likewise, preincubation
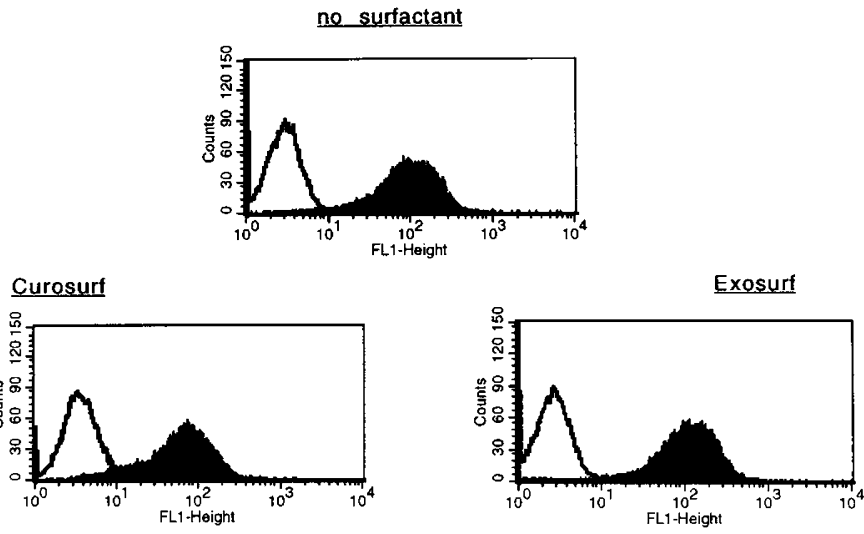

anti-L-Selectin-FITC

no anti-L-Selectin-FITC

Figure 2. Preincubation of lymphocytes with Exosurf or Curosurf does not influence ligand recognition by the L-selectin antibody Dreg56. Lymphocytes were stained with an FITC-conjugated L-selectin antibody and analyzed by flow cytometry. Lymphocytes exhibit an enhanced fluorescence for L-selectin compared with the control cells incubated with an isotype-matched control antibody (mean fluorescence for L-selectin staining was $81 \pm 29$ versus $3.7 \pm$ 0.3 of the control cells; $n=8 ; p<0.02$ ). Preincubation of lymphocytes with Curosurf or Exosurf for $30 \mathrm{~min}$ does not alter ligand recognition by L-selectin compared with untreated cells (mean fluorescence of FITC-L-selectin for Curosurf-treated cells was $71 \pm 46$, for cells incubated with Exosurf, $104 \pm$ $25 ; n=8 ; p>0.2$ ). Incubation of cells with surfactant only does not influence fluorescence in comparison to untreated lymphocytes (mean fluorescence for Curosurf-treated cells was $3.8 \pm 0.1$ and for Exosurf, $3.3 \pm 0.4 ; n=5 ; p>$ $0.2)$.

of Jurkat cells with Curosurf or Exosurf did not prevent recognition of the L-selectin molecule by the Dreg56 antibody (Fig. 2). Therefore, L-selectin-positive lymphocytes are able to interact with their ligands independent of the presence of surfactant.

Inhibition of L-selectin-induced capping of L-selectin molecules by Curosurf and Exosurf. Capping of surface molecules, i.e. focal clustering of receptors, is an energy-dependent process mediated by intracellular signaling molecules (25). Recently, we have demonstrated that L-selectin triggering in Jurkat cells and peripheral blood lymphocytes results in capping of L-selectin molecules with a maximum at $5 \mathrm{~min}(24)$. Here we demonstrate that preincubation of $\mathrm{T}$ lymphocytes with Curosurf or Exosurf resulted in a statistically significant reduction in L-selectin-induced capping (Fig. 3). Incubation of Jurkat cells with surfactant alone did not affect the surface distribution of L-selectin molecules (Fig. 3).

Surfactant diminishes the basal activity of the neutral sphingomyelinase. Because L-selectin triggering activates the neutral sphingomyelinase, resulting in consumption of cellular sphingomyelin and an increase in ceramide (26), we tested the influence of surfactant on the activity of the neutral sphingomyelinase. Incubation of Jurkat $\mathrm{T}$ lymphocytes with Curosurf or Exosurf resulted in a reduction of the basal activity of the neutral sphingomyelinase (Fig. 4, Top). However, the relative increase in activity of the neutral sphingomyelinase on Lselectin triggering was not affected (Fig. 4, Bottom).

L-selectin-induced activation of the src-tyrosine kinase p56lck is inhibited by surfactant. Early signal transduction 


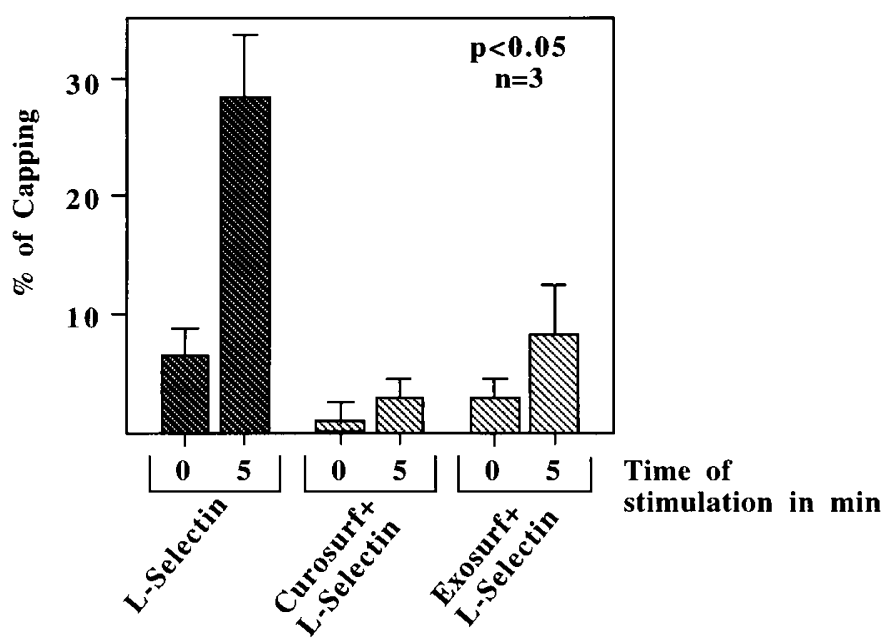

Figure 3. Exosurf and Curosurf inhibit L-selectin-induced capping of Lselectin receptors. Capping of L-selectin molecules was examined by staining with an FITC-conjugated L-selectin antibody in unstimulated and stimulated lymphocytes analyzed by fluorescence microscopy. L-selectin triggering induces capping of L-selectin molecules, whereas preincubation of lymphocytes with Curosurf or Exosurf significantly reduces L-selectin-induced capping ( $t$ test, $p<0.05, n=3$ ).

events in lymphocytes are mediated by src-tyrosine kinases (27). Recently, we have demonstrated that L-selectin crosslinking results in activation of the Ras signaling pathway. This activation was strictly dependent on the activation of the src-tyrosine kinase p56lck as demonstrated by using a genetic approach (11).

We therefore used an in vitro kinase assay to test whether surfactant modulates L-selectin-induced activation of the srctyrosine kinase p56lck. Immunoprecipitates of the src-tyrosine kinase p56lck of stimulated and unstimulated lymphocytes preincubated with or without surfactant were subjected to kinase assay conditions. Preincubation of lymphocytes with surfactant strongly inhibited L-selectin-induced activation of the p561ck kinase (Fig. 5).

The phosphorylation of the adaptor protein $\mathrm{Cbl}$ is inhibited by surfactant. In whole-cell lysates, inhibition of phosphorylation of a protein with an approximate molecular weight of $120 \mathrm{kD}$ was striking (data not shown). In immunoprecipitates, we found that the adaptor protein $\mathrm{Cbl}$, a protein with a molecular size of $120 \mathrm{kD}$, becomes tyrosine phosphorylated on L-selectin stimulation (manuscript in preparation). This tyrosine phosphorylation of the $\mathrm{Cbl}$ protein was abolished when cells were preincubated with surfactant (Fig. 6). In control experiments, surfactant was added after cell lysis, and immunoprecipitates were tested for tyrosine phosphorylation of the Cbl protein. Surfactant does not abolish L-selectin-induced tyrosine phosphorylation of the adaptor protein $\mathrm{Cbl}$ when added after cell stimulation and lysis excluding interference of surfactant with immunoprecipitation (data not shown).

\section{DISCUSSION}

The cellular fraction of bronchoalveolar specimens in healthy humans consists predominantly of alveolar macrophages followed by lymphocytes (28). However, in the course of infection or acute respiratory distress, lymphocytes and

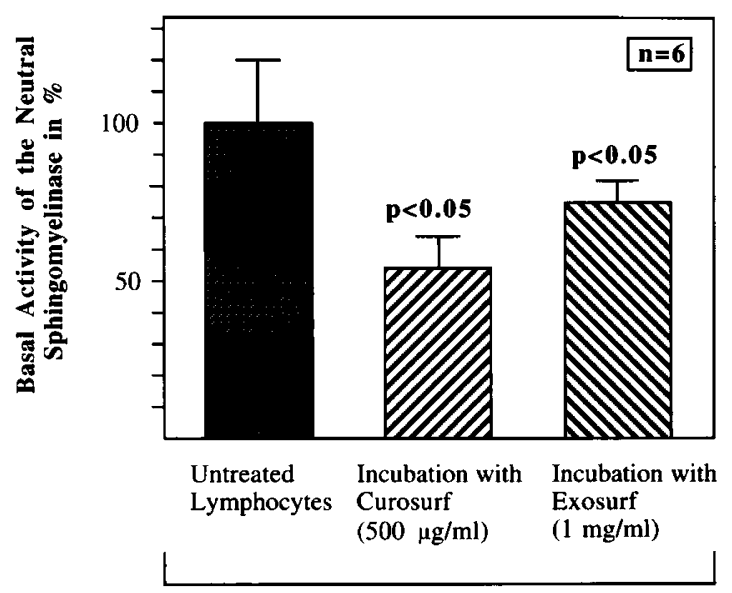

No Antibody Stimulation

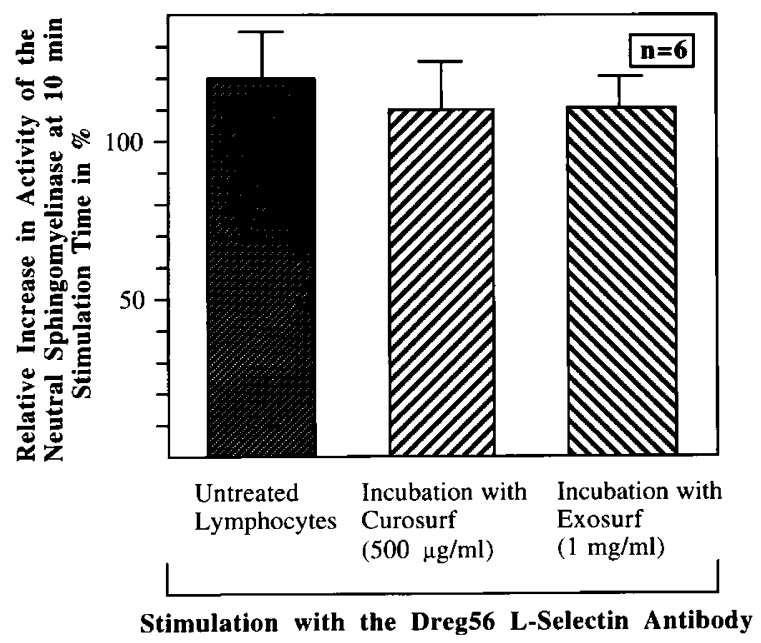

Figure 4. Top, incubation of Jurkat lymphocytes with Curosurf or Exosurf reduces significantly the basal activity of the neutral sphingomyelinase compared with untreated lymphocytes. Bottom, relative increase in the activity of the neutral sphingomyelinase on L-selectin triggering was not affected by surfactant. Cell lysates of untreated lymphocytes, lymphocytes incubated with Curosurf or Exosurf (Top), L-selectin-triggered lymphocytes, and L-selectin-stimulated lymphocytes preincubated with surfactant (Bottom) were added to solubilized $\left[{ }^{14} \mathrm{C}\right]$ sphingomyelin. The degradation of $\left[{ }^{14} \mathrm{C}\right]$ sphingomyelin reflects activity of the neutral sphingomyelinase and was determined by liquid scintillation counting.

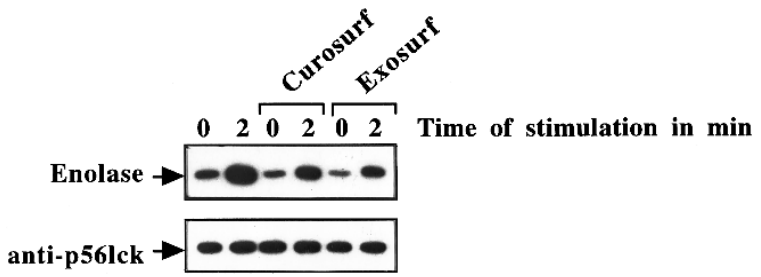

Figure 5. Curosurf and Exosurf diminish L-selectin-induced activation of the tyrosine kinase p56lck. Activity of the src-tyrosine kinase p56lck was measured in immunoprecipitates of the kinase incubated with the substrate enolase. The increase in phosphorylation of the substrate reflects the increase in activation of the p56lck tyrosine kinase. Aliquots of each sample were blotted with an anti-p561ck antibody to check for equal amounts of protein in each lane. Densitometric analysis of three independent src-tyrosine kinase assays revealed that Curosurf and Exosurf inhibit significantly L-selectin-induced activation of the src-tyrosine kinase Lck by $43 \%$ or $51 \%$, respectively.

neutrophils traffic into the intraalveolar space, coming in close contact with surfactant. Besides their role in immune defense, leukocytes account for tissue destruction and chronic inflam- 


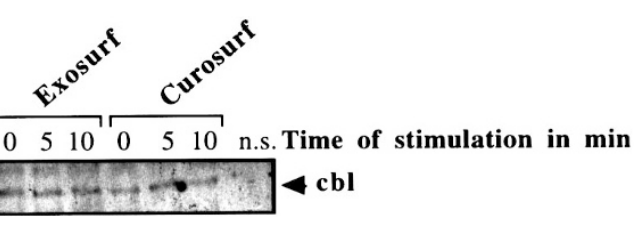

Figure 6. L-selectin triggering induces tyrosine phosphorylation of the adaptor protein $\mathrm{Cbl}$. This increase in tyrosine phosphorylation on L-selectin triggering is abolished in lymphocytes treated with Curosurf or Exosurf. The p120Cbl protein was immunoprecipitated and blotted with an antiphosphotyrosine antibody (4G10). Cells for nonspecific immunoprecipitates (NS) were stimulated with the Dreg56 antibody and incubated with an agarosecoupled antibody only. Results are representative of three independent experiments.

mation (6). For example, chronic inflammatory processes are thought to be important pathogenetic factors in the development of CLD of preterm infants $(29,30)$.

The long-term benefit of surfactant in the course of severe RDS of premature infants is well established [reviewed in Pramanik et al. (31) and Pelkonen et al. (32)]. In addition, there is increasing evidence that surfactant inhibits bacterial growth and modulates immunologic functions of inflammatory cells $(17,33)$. Mitogen- or antigen-induced proliferation and immunoglobulin synthesis of lymphocytes are reduced by surfactant (34-37). Inhibition of LPS-induced release of tumor necrosis factor- $\alpha$, the anti-inflammatory IL-1 receptor antagonist, and other proinflammatory cytokines (such as IL-1, IL-6, and IL-8) in monocytes by different surfactant preparations underscores the immunomodulatory role of surfactant $(20,21,23,38)$. Production of superoxide anions and release of prostaglandin $\mathrm{E}_{2}$ and thromboxane $\mathrm{B}_{2}$ in monocytes by a bacterial extract were significantly inhibited by Curosurf (22). The molecular mechanisms in the surfactant-induced inhibition of bactericidal functions of monocytes comprise intracellular signaling pathways involving protein kinases (39).

The influence of surfactant on intracellular signaling events of adhesion molecules is relatively unknown. Our present study revealed that two different surfactant preparations significantly inhibit L-selectin-induced capping of selectin receptors. Capping of membrane-bound surface receptors is an energydependent process mediated by intracellular, yet unknown, molecules and seems to be important in inducing intracellular signaling cascades (25) in leukocytes. In addition, surfactant reduces the basal activity of the neutral sphingomyelinase on L-selectin triggering. Recently, we have demonstrated that inhibition of the neutral sphingomyelinase by glutathione, a pharmacologic inhibitor (40), abolishes L-selectin-induced capping (24). Therefore, the surfactant-induced prevention of capping after L-selectin triggering might be related to the inhibitory effects on the activity of the neutral sphingomyelinase. Furthermore, surfactant inhibits the L-selectin-induced activation of the src-tyrosine kinase p561ck, resulting in the lack of phosphorylation of several proteins. Activation of src-tyrosine kinase is one of the earliest events in intracellular signaling known so far (41). Src-tyrosine kinases play a fundamental role in transmitting signals, thereby modulating cell proliferation and differentiation. Inhibition of this kinases might therefore have a profound effect on cellular functions in leukocytes. The p120Cbl protein was identified as a molecule whose tyrosine phosphorylation was abolished by surfactant. The function of this protein is not fully understood yet. However, p120Cbl is an adaptor protein, enabling the activationdependent assembly of multiprotein complexes, thereby fulfilling docking functions (42). Lack of phosphorylation of the p120Cbl protein could therefore result in disintegration of multiprotein complexes and disturbance of intracellular signaling.

The exact pharmacologic mechanisms by which surfactant exerts these effects on lymphocytes are not understood yet. Using a flow cytometric approach, we could clearly exclude that the inhibitory effects of both surfactant preparations tested on L-selectin-induced signal transduction are related to disturbed interaction of the L-selectin antibody with the L-selectin receptor molecule.

One can speculate that because of the biophysical properties of surfactant, phospholipids are integrated in cellular membranes and modulate the assembly of cell membrane-anchored multiprotein complexes. Alternatively, surfactant might directly interact with intracellular signaling molecules.

We experimentally excluded the possibility that surfactant might interfere with a certain step within the assays by demonstrating that adding surfactant to immunoprecipitates does not influence tyrosine phosphorylation of the $\mathrm{Cbl}$ protein. In addition, a direct effect on the assays is very unlikely because the various assays are based on completely different biochemical methods, such as immunoprecipitation, immunofluorescence, and enzymatic reactions.

Finally, we used Curosurf at a concentration of $500 \mu \mathrm{g} / \mathrm{mL}$ and Exosurf at a concentration of $1000 \mu \mathrm{g} / \mathrm{mL}$. The concentration of surfactant in the intraalveolar space is difficult to estimate. From studies by Gregory and coworkers (43), who analyzed the phospholipid content from bronchoalveolar lavages, the amount of phospholipid concentration in the surfactant preparation inhibiting L-selectin-induced signal transduction is in the lower range compared with that present in the alveoli of the healthy lung and is similar to the phospholipid content in the lavage from patients with adult respiratory distress syndrome.

Of interest will be to dissect which components of the natural surfactant Curosurf and of the synthetic surfactant Exosurf contribute to the described effects. As far as Exosurf is concerned, the suppressive effects on chemokine synthesis seem to rely on the dispersing agent tyloxapol (44).

The suppressive effects of surfactant on intracellular signaling events of the L-selectin adhesion molecule might be beneficial. The physiologic role of L-selectin in adhesion is in mediating transient interactions of leukocytes with endothelial cells. This L-selectin-mediated tethering and rolling is a prerequisite for integrin-dependent firm sticking and extravasation. These interactions of the L-selectin molecule with its ligands also induce intracellular signaling cascades and activate leukocytes. Activation of leukocytes by L-selectin also takes place in the intraalveolar space during inflammatory processes. There is an elevated level of soluble L-selectin in tracheal aspirates of preterm infants with RDS who subsequently have CLD (16). An elevated level of soluble selectin reflects L-selectin-induced cell activation, resulting in the pro- 
teolytic cleavage of the extracellular domain of L-selectin. This unintentional L-selectin triggering in the intraalveolar space might be induced by ligands expressed on other leukocytes or platelets. Of note is that L-selectin acts as a low-affinity receptor for LPS and that L-selectin is the first known cell surface protein that both binds LPS and transduces signals (45). In addition, LPS induces shedding of L-selectin. Although the pathogenesis of adult respiratory distress syndrome, $\mathrm{RDS}$, and pneumonia is diverse, these diseases are characterized by intraalveolar accumulation and activation of leukocytes.

Therefore, attenuation of L-selectin-mediated signal transduction in lymphocytes by surfactant might reduce tissue destruction and chronic inflammation and could contribute to the anti-inflammatory effects of surfactant.

\section{REFERENCES}

1. Welbourn CRB, Young Y 1992 Endotoxin, septic shock and acute lung injuryneutrophil, macrophages and inflammatory mediators. Br J Surg 79:998-1003

2. Merritt TA, Stuard ID, Puccia J, Wood B, Edwards DK, Finkelstein J, Shapiro DL 1981 Newborn tracheal aspirate cytology: classification during respiratory distress syndrome and bronchopulmonary dysplasia. J Pediatr 98:949-956

3. Jutila MA 1992 Leukocyte traffic to sites of inflammation. APMIS 100:191-201

4. Kelly J 1990 Cytokines of the lung. Am Rev Respir Dis 141:765-788

5. Merritt TA, Cochrane CG, Holcomb K, Bohl B, Hallman M, Strayer D, Edwards II DK, Gluck L 1983 Elastase and $\alpha 1$-proteinase inhibitor activity in tracheal aspirates during respiratory distress syndrome. J Clin Invest 72:656-666

6. Weiss SJ 1989 Tissue destruction of neutrophils. N Engl J Med 320:365-376

7. Groneck P, Goetze-Speer B, Oppermann M, Eiffert H, Speer CP 1994 Association of pulmonary inflammation and increased microvascular permeability during the development of bronchopulmonary dysplasia: a sequential analysis of inflammatory mediators in respiratory fluids of high-risk preterm neonates. Pediatrics 93:712-718

8. Stefano JL, Spear ML, Pearlman SA, Fawcett P, Proujansky R 1992 Soluble IL-2 receptor levels in infants with bronchopulmonary dysplasia. Pediatr Pulmono $14: 58-62$

9. Laudanna C, Constantin G, Baron P, Scarpini E, Scarlato G, Cabrini G, Dechecchi C, Rossi F, Cassatella MA, Berton G 1994 Sulfatides trigger increase of cytosolic free calcium and enhanced expression of tumor necrosis factor- $\alpha$ and IL- 8 mRNA in human neutrophils. J Biol Chem 269:4021-4026

10. Waddell TK, Fialkow L, Chan CK, Kishimoto TK, Downey GP 1995 Signaling functions of L-selectin. J Biol Chem 270:15403-15411

11. Brenner B, Gulbins E, Schlottmann K, Koppenhoefer U, Busch GL, Walzog B, Steinhausen M, Coggeshall KM, Linderkamp O, Lang F 1996 L-selectin activates the Ras pathway via the tyrosine kinase p561ck. Proc Natl Acad Sci USA 93:1537615381

12. Brenner B, Gulbins E, Busch GL, Koppenhoefer U, Lang F, Linderkamp O 1997 L-selectin regulates actin polymerization via activation of the small G-protein Rac2. Biochem Biophys Res Commun 231:802-807

13. Brenner B, Weinmann S, Grassmé H, Lang F, Linderkamp O, Gulbins E 1997 L-selectin activates JNK via src-like tyrosine kinases and the small G-protein Rac. Immunology 92:214-219

14. Tullus K, Noack GW, Burman LG, Nilsson R, Wretlind B, Brauner A 1996 Elevated cytokine levels in tracheobronchial aspirate fluids from ventilator treated neonates with bronchopulmonary dysplasia. Eur J Pediatr 155:112-116

15. Jung TM, Dailey MO 1990 Rapid modulation of homing receptors (gp90 $0^{\mathrm{MEL}-14}$ ) induced by activators of protein kinase C. J Immunol 144:3130-3136

16. Kotecha S, Silverman M, Shaw RJ, Klein N 1998 Soluble L-selectin concentration in bronchoalveolar lavage fluid obtained from infants who develop chronic lung disease of prematurity. Arch Dis Child Fetal Neonatal Ed 78:F143-F147

17. Van Iwaarden J 1992 Surfactant and the pulmonary defense system. In: Robertson B, van Golde L, Batenburg J (eds) Pulmonary Surfactant: From Molecular Biology to Clinical Practice. Elsevier, Amsterdam, pp 215-254

18. Jutila MA, Kishimoto TK, Butcher EC 1990 Regulation and lectin activity of the human neutrophil peripheral lymph node homing receptor. Blood 76:178-183

19. Kishimoto TK, Jutila M, Butcher EC 1990 Identification of a human peripheral lymph node homing receptor: a rapidly down-regulated adhesion molecule. Proc Natl Acad Sci USA 87:2244-2248
20. Thomassen MJ, Meeker DP, Antal JM, Connors MJ, Wiedemann HP 1992 Synthetic surfactant (Exosurf) inhibits endotoxin-stimulated cytokine secretion by human alveolar macrophages. Am J Respir Cell Mol Biol 7:257-260

21. Antal JM, Divis LT, Erzurum SC, Wiedemann HP, Thomassen MJ 1996 Surfactant suppresses NF-kappa B activation in human monocytic cells. Am J Respir Cell Mol Biol 14:374-379

22. Walti H, Polla BS, Bachelet M 1997 Modified natural porcine surfactant inhibits superoxide anions and proinflammatory mediators released by resting and stimulated human monocytes. Pediatr Res 41:114-119

23. Baur FM, Brenner B, Goetze-Speer B, Neu S, Speer CP 1998 Natural porcine surfactant (Curosurf) down-regulates mRNA of tumor necrosis factor- $\alpha$ (TNF- $\alpha$ ) and TNF- $\alpha$ type II receptor in lipopolysaccharide-stimulated monocytes. Pediatr Res $44: 32-36$

24. Junge S, Brenner B, Lepple-Wienhuis A, Nilius B, Lang F, Linderkamp O, Gulbins E 1999 Intracellular mechanisms of L-selectin induced capping. Cell Signal 11:301308

25. Pasternak C, Spudich JA, Elson EL 1989 Capping of surface receptors and concomitant cortical tension are generated by conventional myosin. Nature 341:549-551

26. Brenner B, Grassmé HUC, Müller C, Lang F, Speer CP, Gulbins E 1998 L- selectin stimulates the neutral sphingomyelinase and induces release of ceramide. Exp Cell Res 243:123-128

27. Sefton BM, Taddie JA 1994 Role of tyrosine kinases in lymphocyte activation. Curr Opin Immunol 6:372-379

28. Reynolds HY, Newball HH 1974 Analysis of proteins and respiratory cells obtained from human lungs by bronchial lavage. J Lab Clin Med 84:559-573

29. Saugstad OD 1997 Bronchopulmonary dysplasia and oxidative stress: are we closer to an understanding of the pathogenesis of BPD? Acta Paediatr 86:1277-1282

30. Groneck P, Goetze-Speer B, Oppermann M, Eiffert H, Speer CP 1994 Association of pulmonary inflammation and increased microvascular permeability during the development of bronchopulmonary dysplasia: a sequential analysis of inflammatory mediators in respiratory fluids of high-risk preterm neonates. Pediatrics 93:712-718

31. Pramanik AK, Holtzman RB, Merritt TA 1993 Surfactant replacement therapy for pulmonary diseases. Pediatr Clin North Am 40:913-936

32. Pelkonen AS, Hakulinen AL, Turpeinen M, Hallman M 1998 Effect of neonatal surfactant therapy on lung function at school age in children born very preterm. Pediatr Pulmonol 25:182-190

33. Herting E, Sun B, Jarstrand C, Curstedt T, Robertson B 1997 Surfactant improves lung function and mitigates bacterial growth in immature ventilated rabbits with experimentally induced neonatal group B streptococcal pneumonia. Arch Dis Child Fetal Neonatal Ed 76:F3-F8

34. Woerndle S, Bartmann P 1994 The effect of three surfactant preparations on in vitro lymphocyte functions. J Perinat Med 22:119-128

35. Roth MD, Pinto M, Golub SH, Shau H 1993 Pulmonary surfactant inhibits IL-2induced proliferation and the generation of lymphokine-activated killer cells. Am J Respir Cell Mol Biol 9:652-658

36. Bartmann P, Gortner L, Pohlandt F, Jaeger H 1992 In vitro lymphocyte functions in the presence of bovine surfactant and its phospholipid fractions. J Perinat Med 20:189-196

37. Richman PM, Spragg RG, Asser SM, Merritt TA, Notter RH, Robertson B 1987 Comparison of the safety of three surfactant preparations for human use. Pediatr Res 21:464A

38. Allen J, Moore SA, Pope-Harman AL, Marsh CB, Wewers MD 1995 Immunosuppressive properties of surfactant and plasma on alveolar macrophages. J Lab Clin Med $125: 356-369$

39. Geertsma MF, Zomerdijk TP, Nibbering PH, van Furth R 1994 Pulmonary surfactant inhibits monocyte bactericidal functions by altering activation of protein kinase $\mathrm{A}$ and C. Immunology 83:133-139

40. Liu B, Hannun YA 1997 Inhibition of the neutral magnesium-dependent sphingomyelinase. J Biol Chem 272:16281-16287

41. Sefton BM, Taddie JA 1994 Role of tyrosine kinases in lymphocyte activation. Curr Opin Immunol 6:372-379

42. Liu Y-C, Altman A 1998 Cbl: complex formation and functional implications. Cell Signal 10:377-385

43. Gregory TJ, Longmore WJ, Moxley MA, Whitsett JA, Reed CR, Fowler AA, Hudson LD, Maunder RJ, Crim C, Hyers TM 1991 Surfactant chemical composition and biophysical activity in acute respiratory distress syndrome. J Clin Invest 88:19761981

44. Thomassen MJ, Antal JM, Divis LT, Wiedemann HP 1995 Regulation of human alveolar macrophage inflammatory cytokines by tyloxapol: a component of the synthetic surfactant Exosurf. Clin Immunol Immunopathol 77:201-205

45. Malhotra R, Bird MI 1997 L-selectin: a novel receptor for lipopolysaccharide and its potential role in bacterial sepsis. Bioessays 19:919-923 